\title{
THE EFFECTS OF SPECIAL SAVING PROGRAMS ON SAVING AND WEALTH
}

James M. Poterba

Steven F. Venti

David A. Wise

Working Paper 5287

\section{NATIONAL BUREAU OF ECONOMIC RESEARCH 1050 Massachusetts Avenue \\ Cambridge, MA 02138 \\ October 1995}

This paper was prepared for the NBER/JCER Joint Conference on the Economics of Aging, September, 1993. We are grateful to the Japan Foundation Center for Global Partnership, the U.S. National Institute of Aging and the National Science Foundation for research support. Sections of this paper draw heavily on earlier papers on this topic by the same authors. We thank Charles Horioka for his thoughtful and detailed comments on the paper. This paper is part of NBER's research programs in Aging and Public Economics. Any opinions expressed are those of the authors and not those of the National Bureau of Economic Research.

() 1995 by James M. Poterba, Steven F. Venti and David A. Wise. All rights reserved. Short sections of text, not to exceed two paragraphs, may be quoted without explicit permission provided that full credit, including $\odot$ notice, is given to the source. 


\title{
THE EFFECTS OF SPECIAL SAVING PROGRAMS ON SAVING AND WEALTH
}

\begin{abstract}
Individual saving through targeted retirement saving accounts_-IRAs and 401(k)s—grew rapidly in the United States during the 1980s. The microeconomic evidence presented in this paper suggests that most of the contributions to these programs represent new saving that would not otherwise have occurred. The micro evidence is compared with macro saving measured by National Income and Product Accounts and Flow of Funds data.
\end{abstract}

James M. Poterba Department of Economics MIT Cambridge, MA 02139 and NBER
Steven F. Venti

Department of Economics Dartmouth College Hanover, NH 03755 and NBER
David A. Wise

Kennedy School of Govermment Harvard University Cambridge, MA 02138 and NBER 
The last decade has witnessed important changes in the way Americans save for retirement. In particular, Individual Retirement Accounts (IRAs) and 401(k) plans have become popular targeted retirement saving vehicles. The IRA and $401(\mathrm{k})$ asset accumulation of many households is substantially greater than the combined value of their other financial assets. If current contribution patterns persist, the next generation of retirees will derive a substantial fraction of its support from resources accumulated in these accounts.

This paper provides an overview of the nature of targeted retirement saving programs in the United States and a summary of the effects of these programs on the saving behavior and wealth of U.S. households. The paper is divided into five sections. The first presents descriptive information on the structure of IRAs and 401(k)s, and summarizes the changing patterns of participation in this programs during the last decade. Section two summarizes information on the relative importance of assets in household wealth. The third section draws on previous studies of both IRA and 401(k) contributors to address the extent to which contributions to these special accounts represent "new saving." Section four explores the relationship between the enormous increase in personal targeted retirement saving in the 1980s and aggregate measures of personal saving in the United States. There is a brief conclusion. 


\section{The Structure of Special Saving Plans}

Employer provided pension plans have been the dominant retirement saving vehicle for U.S. households throughout much of the post-war period. Employer contributions to these plans can be deducted from corporate income taxes and income accruing on pension plan assets is also tax-exempt. Employees are not taxed on their pension entitlement until they receive benefits, typically many years after contributions are made.

During the 1980 s, however, a number of specialized programs designed to encourage household saving were introduced, and in some cases, subsequently restricted. These programs, principally IRAs and 401(k)s, offer many of the same tax benefits as traditional employer-provided pensions. While a variety of regulatory and tax changes reduced the appeal of traditional pension arrangements during the 1980s, the new retirement saving vehicles flourished. This section describes the increasinglypopular specialized saving plans and also presents some information on more traditional pension arrangements.

\subsection{IRAs and 401(k)s: The Rules}

Individual Retirement Accounts (IRAs) were created by the Economic Recovery Tax Act of 1981. As originally enacted, taxpayers could make tax-deductible 
contributions to IRAs subject to a limit of $\$ 2000$ per earner and $\$ 250$ for a nonworking spouse. Withdrawals could be made without penalty any time after the account-holder turned $591 / 2$, while early withdrawals were subject to a $10 \%$ tax penalty. Withdrawals are taxed as ordinary income. The power of compound interest makes the IRA an advantageous vehicle for long-term saving.

To reduce the current revenue cost of this program, the Tax Reform Act of 1986 limited access to tax-deductible IRAs by imposing income tests on deductible contributions by taxpayers covered by an employer-sponsored pension plan. Single taxpayers with incomes less than $\$ 25,000$, and joint filers with taxable incomes less than $\$ 40,000$, could make fully-deductible contributions. Now single filers with incomes above $\$ 35,000$, and joint filers with incomes above $\$ 50,000$, can not make tax-deductible contributions. Taxpayers with incomes between the thresholds for taxdeductible and taxable IRAs are eligible for partially-deductible IRAs. Taxpayers with employer-sponsored pensions and incomes above the various thresholds can still make after-tax contributions and the return on the contributions accrues tax-free. As a rough approximation, for those affected by the legislation, about one-half of the advantage of the IRA over conventional saving vehicles was removed.

The 1986 tax changes reduced the attractiveness of saving through IRAs for many households, and we will show below that participation rates in IRAs declined. A 
second retirement saving program, known as the $401(\mathrm{k})$ plan after that section of the Internal Revenue Code, was growing in importance throughout the 1980s. The 401(k) plans were established by 1978 legislation, but they expanded rapidly only after the Treasury Department clarified their operation in 1981. These plans are established by employers. They allow employees to contribute before-tax dollars to $401(\mathrm{k})$ accounts. Like IRAs, assets in 401(k) plans accumulate tax-free, and, just as with IRAs, income from these plans is taxed only when the funds are withdrawn. Prior to 1987 the employee contribution limit was $\$ 30,000$. The Tax Reform Act of 1986 reduced the limit to $\$ 7,000$ beginning in 1987 and instituted indexation for inflation in subsequent years. The 1993 contribution limit is $\$ 8,994$.

There are several additional features of $401(\mathrm{k}) \mathrm{s}$ that employers may choose to adopt. First, employers can "match" employee contributions. A recent Hewitt [1991] study of 677 medium and large size employers found that 84 percent of $401(\mathrm{k})$ plans provide some employer matching, 31 percent match at 50 cents per dollar, and 11 percent match dollar for dollar. A 1993 survey of 401(k) plans by Papke, Petersen, and Poterba [1993] finds that nearly ninety percent of the participants in 401(k) plans face match rates of at least 25 cents per dollar contributed, and one third face match rates of 100 percent on at least part of their contributions. ${ }^{1}$

\footnotetext{
${ }^{1}$ The response rate to this survey was just over 5 percent, however. Nonetheless, Papke, Peterson, and Poterba [1993] present some evidence that the attributes of respondent plans are similar 
A second important feature of many 401(k) plans is "hardship withdrawal," that enables participants to access plan funds, although in some cases with a penalty payment. Such withdrawals have tax consequences, since the withdraw is treated as taxable income in the year when it is received. ${ }^{2}$ Employees in many firms may also borrow funds from their $401(\mathrm{k})$ accounts.

Conventional financial calculations, emphasizing rates of return, demonstrate that the $401(\mathrm{k})$ investment strictly dominates even a fully deductible IRA whenever the employer match rate is positive. On this criterion, deductible as well as non-deductible IRAs also dominate saving through traditional taxable accounts. For individuals aged $591 / 2$ or greater there are no penalties associated with withdrawal of IRA or 401(k) funds, so these accounts strictly dominate ordinary investment accounts. For younger investors, the rate of return benefit from investing through a targeted account must be compared with the reduced liquidity of assets in these accounts. Because we believe that most households don't save according to a simple rate-of-return-maximizing

to those in other larger surveys of $401(\mathrm{k})$ plans. Many $401(\mathrm{k})$ plans provide high employer match rates up to a fixed fraction of salary (often 5\%) contributed to the plan. After reaching this matching limit, employees may still make contributions, provided they have not reached the IRS limit on contributions, but those contributions will not be matched.

${ }^{2}$ Leaving the firm that offers the $401(\mathrm{k})$ plan can also trigger a withdraw if an individual has a relatively small $401(\mathrm{k})$ account balance and the employer chooses to terminate the account. The plan balance is transferred to the participant as a "lump sum distribution." The recipient can then choose either to reinvest the proceeds in a tax-free account such as an IRA, or to treat the lump sum distribution as current taxable income. 
strategy, however, we suspect that return considerations affect but are not the most important determinant of saving behavior. ${ }^{3}$

Although IRAs and 401(k) plans are the two most important personal retirement saving plans, other programs that are available to specific groups. One such program is the 403(b) tax-sheltered annuity plan for employees of educational and some other non-profit institutions. These plans allow taxpayers to make retirement contributions from before-tax dollars, just as with $401(\mathrm{k})$ plans, and they permit tax-free accumulation subject to some restrictions on withdrawal. The current limit on contributions to a $403(\mathrm{~b})$ plan is $\$ 9500$ per year. Another such program, known as a Keogh plan, is a retirement plan for self-employed persons. These plans are effectively substitutes for the employer-provided defined contribution (and defined benefit) plans provided for employees, and offer the same tax treatment and the same favorable opportunities for investment. There are limits on contributions. In most cases, an individual cannot contribute more than 20 percent of total earnings, or $\$ 30000$, whichever is smaller. Because these plans apply to limited segments of the population, our subsequent analysis focuses on IRAs and 401(k)s.

\footnotetext{
${ }^{3}$ For discussion of this issue see Venti and Wise [1992] and Poterba, Venti, and Wise [1994, 1993].
} 


\subsection{Participation in IRAs and 401(k)s}

The number of taxpayers making IRA contributions in each year since the early 1980s is shown in Table 1.1. IRAs became popular almost immediately after they were introduced, and at their peak in 1985 more than sixteen million taxpayers contributed nearly $\$ 40$ billion to these accounts. The changes imposed in Tax Reform Act of 1986 reduced the incentives for some households to contribute, by eliminating deductible contributions for some higher income taxpayers and by reducing marginal tax rates on capital income accruing through traditional channels. There was also a substantial decline in IRA promotion by financial institutions in the post-1986 period. Many taxpayers who could have made tax-deductible contributions in the post-1986 period also appear to have been confused about the new IRA rules, and therefore erroneously concluded that they were not eligible for the program. The number of contributors fell by half between 1986 and 1987 . Indeed, even taxpayers who were unaffected by the new IRA contribution provisions and whose tax rates were unaffected by the legislation reduced their contribution rates by about 40 percent. By 1990 , fewer than six million taxpayers reported IRA contributions of just under ten billion dollars.

The number of $401(\mathrm{k})$ plan and participants and contributions over the $1980 \mathrm{~s}$ is reported in Table 1.2. The table charts the rapid growth of 401(k) plans during the last decade. Between 1984 and 1989, the number of plans more than quadrupled, and the 
number of participants more than doubled. ${ }^{4}$ Contributions increased even more than the number of participants, even though the Tax Reform Act of 1986 limited the maximum contribution. The number of employees making $401(\mathrm{k})$ contributions is now substantially larger than the number of IRA contributors. These plans are now available at virtually all large firms, and are diffusing through smaller firms as well.

Data on traditional defined benefit and defined contribution pension plans is shown in Table 1.3. The number of defined contribution plans more than doubled between 1975 and 1982, and then rose sharply again after 1985 . The value of contributions to these plans, however, peaked in the early 1980 s and has remained relatively constant since that time. (The somewhat larger figures in 1982 and 1983 include 401(k) contributions; contributions to defined contribution plans changed little over the period.) In 1989 , contributions to $401(\mathrm{k})$ plans were substantially greater than contributions to defined contribution pension plans. ${ }^{5}$ The number of defined benefit plans increased during the 1975-1982 period, but the increase was slower than that for defined contribution plans. Between 1986 and 1989, however, the number of defined benefit plans declined by 23 percent. The number of active participants in defined benefit plans peaked in 1984 and declined 9.6 percent by 1989 . Contributions to

${ }^{4}$ Participation in a plan only indicates that an employee has a $401(\mathrm{k})$ account, not that he made a contribution in a given year.

${ }^{5}$ For some purposes, $401(\mathrm{k})$ plans are considered defined contribution plans. Our discussion of defined contribution plans focuses on non-401(k) plans. 
defined benefit plans reached a peak in 1982 and declined by 48.6 percent by 1989 . These trends in the flow of pension contributions are important factors in aggregate personal saving, an issue we consider in more detail below.

A key difference between IRAs and $401(\mathrm{k}) \mathrm{s}$ is that while all taxpayers are eligible for IRAs, with varying degrees of tax-deductibility, 401(k) eligibility is conditional on the individual's employer offering a plan. To estimate the participation rate in $401(\mathrm{k})$ plans conditional on eligibility therefore requires data on either individuals or firms. Table 1.4 presents information on both $401(\mathrm{k})$ eligibility and participation given eligibility, based on tabulations from the Survey of Income and Program Participation. The analysis is limited to households with heads between the ages of 25 and 65, and excludes households with self-employment income. Conditional on eligibility, the participation rate in $401(\mathrm{k})$ plans increased from 58.1 percent in 1984 to 70.8 percent in 1991 . The third column in Table 1.4 gives the overall 401(k) participation rate, which is the product of the eligibility rate in column (1) and the conditional participation rate in column (2). By 1991 almost one-quarter of all families participated in a $401(\mathrm{k})^{6}$

${ }^{6}$ One important feature of $401(\mathrm{k})$ plan participation, underscored by Papke, Petersen, and Poterba's (1993) cross-tabulations of plan characteristics in several different years, is a strong persistence in participation. Because participation rates in most $401(\mathrm{k}) \mathrm{s}$ are high, and consistently high, there is strong evidence that individuals who begin saving through $401(\mathrm{k})$ arrangements will continue to do so. 
For comparison, the last column in Table 1.4 shows the participation rate in IRAs. The percent of families with an IRA has never exceeded 30 percent. These figures are the percent of families that have a positive balance in an IRA each year. Since many families may have an IRA but no longer make contributions, the figures overestimate the IRA participation rate.

Eligibility and participation rates by age and income are shown for 1991 in Table 1.5. Eligibility for a $401(\mathrm{k})$ increases with income, but is not strongly related to age. Given eligibility, participation is unrelated to age but increases somewhat with income; conditional participation is above 60 percent for all income groups, however. The relationship between income and 401(k) participation shown in the third panel of the table is due largely to the relationship of eligibility to income. In contrast, participation in an IRA, for which all wage earners were eligible until 1986, is strongly related to both age and income. Thus, comparing the second and the fourth panels of the table, conditional $401(\mathrm{k})$ participation is much more equally distributed, than IRA participation, across age and income groups.

The data in Table 1.5 suggest that the diffusion of $401(\mathrm{k})$ plans may have the greatest effect on retirees who reach retirement age in two or three decades. Indeed, the eligibility rate for $401(\mathrm{k}) \mathrm{s}$ is highest among workers between the ages of 35 and 45 . 
The high 401(k) participation rates suggest that the special features of $401(\mathrm{k})$ plans -- payroll deduction of contributions, other employees also contributing, and often-generous employer match rates -- are important aspects of the plan. The high 401(k) participation rates also suggest that as these plans diffuse across firms, and more workers become eligible, there will be increased use of $401(\mathrm{k}) \mathrm{s}$ for retirement saving.

\subsection{Contributions to IRAs and $401(\mathrm{k}) \mathrm{s}$}

Figure 1.1 shows the trend in total contributions to $401(\mathrm{k})$ and IRA accounts. IRA contributions increased from less than $\$ 5$ billion to almost $\$ 30$ billion as soon as they became available to all wage earners in 1982. Thereafter annual contributions increased to almost $\$ 40$ billion in 1986 . But the Tax Reform Act of 1986 led to a dramatic reduction in IRA contributions, that were less than $\$ 10$ billion by 1990 . Annual contributions to 401(k) plans began at a low level in 1982 and then increased continuously, reaching almost $\$ 46$ billion in 1989 . Contributions were probably close to $\$ 60$ billion by the early 1990 s. The graph shows little relationship between IRA and 401(k) saving. In particular, the data show no increase in the rate of growth in $401(\mathrm{k})$ contributions after the Tax Reform Act of 1986 and the subsequent fall in IRA contributions. 
A useful measure of the importance of IRA and 401(k) contributions is their level relative to other contributions that are targeted to providing retirement income. There is an obvious difficulty in measuring such retirement saving, since it is not possible to "track" all dollars of saving as targeted for particular uses. Nevertheless, it is plausible to define total new private retirement saving contributions as the sum of employer contributions to defined benefit and defined contribution pension plans and individual contributions to IRAs, Keogh plans, and 401(k) plans.

The relative importance of the different components of retirement saving during the 1980s are plotted in Figure 1.2. By 1989, IRAs, 401(k)s, and Keogh plans together accounted for almost 53 percent of total retirement saving, up from 7.6 percent in 1980 . It seems evident that if IRA contributions had not been reduced by the Tax Reform Act of 1986 , this proportion would be substantially higher. Thus these new saving vehicles have rapidly become an extremely important component of the future financial support of the elderly. Counting defined contribution pension plans, 76 percent of 1988 retirement saving was in "individual" accounts, with a value that the individual can track and assets that the individual can manage to some degree. By comparison, only 43 percent of retirement saving flowed into such accounts in 1980 .

Figure 1.2 shows that total retirement saving increased sharply until 1985 and fell substantially thereafter, following the Tax Reform Act of 1986 . Essentially the 
pattern of total retirement saving follows the pattern of IRA contributions. Indeed, if it had not been for $401(\mathrm{k})$ contributions, the data suggest that total retirement saving would have fallen much more than it did. In spite of the increase in the number of defined contribution pension plans, total contributions to these plans remained almost constant over the entire period. There was a large drop in contributions to defined benefit pension plans. ${ }^{7}$ Bernheim and Shoven [1988] discuss a number of explanations for this develop, principally increases in the value of pension funds invested in the stock market and thus lower required additional contributions to meet projected benefit entitlements. Schieber and Shoven [1993] discuss in addition the effect of legislation in the in the 1980 s that limited contributions to defined benefit plans.

\section{Account Balances in Targeted Saving Plans}

The U.S. wealth distribution is highly skewed, and mean holdings of virtually all assets are much greater than median holdings. To provide information on the saving patterns of representative households, we therefore focus on median balances in IRAs and $401(\mathrm{k})$ accounts, as well as median holdings of other financial assets.

\footnotetext{
${ }^{7}$ The rapid expansion of $401(\mathrm{k})$ plans at a time when more traditional retirement saving arrangements were either stable or declining raises a question about whether $401(\mathrm{k})$ s were substitutes for other pension programs. The evidence in Papke, Petersen, and Poterba (1993) suggests most 401(k) participants are in plans that supplement other pension plans. There is some evidence that small firms may now choose $401(\mathrm{k}) \mathrm{s}$ rather than other types of retirement saving programs.
} 
Table 2.1a shows the median holdings of all financial assets and median balances in targeted saving plans, by individuals with and without IRAs, in 1984, 1987, and 1991. In 1984, the median IRA balance of households with IRAs was $\$ 4500$. The median of non-IRA financial assets, excluding (including) stocks and bonds, was $\$ 6550$ $(\$ 9400) .^{8}$ By 1991 , the median IRA balance in households with an IRA was $\$ 10,500$, and the median non-IRA balance $\$ 7,867$ ( $\$ 10,900$ including stocks and bonds). While the characteristics of the median IRA household may have changed between 1984 and 1991, the striking feature of these statistics is the small increase in non-IRA asset holdings, measured with or without stocks and bonds. Moreover, these statistics demonstrate that balances in IRA accounts represent a substantial fraction of the financial asset holdings of households with these accounts.

The lower panel of Table 2.1a presents summary information on households without IRAs. The median financial assets for this group was only $\$ 1500$ in 1991 , including holdings of stocks and bonds, and had been only $\$ 800$ seven years earlier. The low level of median asset holdings indicates that a majority of households save very little. The finding that median non-IRA financial assets change very slowly for

${ }^{8} \mathrm{Because}$ Table $2.1 \mathrm{~b}$ reports medians, and medians are not additive, there is no requirement for the median of the sum of two exhaustive asset categories, for example IRA balances and non-IRA balances, to add to the median of total financial assets. 
both groups of households is important evidence on the net effect of IRAs on personal saving, a subject we consider in more detail below.

Table $2.1 \mathrm{~b}$ presents statistics similar to those in Table $2.1 \mathrm{a}$, except it divides households based on whether they have a 401(k) plan, rather than an IRA. The broad pattern of results is similar to that for IRAs. Households without $401(\mathrm{k}) \mathrm{s}$ have very low levels of total financial assets. The median non-401(k)-non-IRA assets of households with 401(k)s declines slightly between 1984 and 1987, and changes relatively little in the next four years. The difference between 1984 and 1987 may not reflect actual asset decumulation by $401(\mathrm{k})$ households, but rather changes in the composition of the set of households with 401(k) plans over the time period.

Two caveats are important in interpreting Table 2.1. First, because most households have at least some net worth in owner-occupied real estate in addition to the financial assets described in Table 2.1, 401(k) and IRA accounts are a smaller fraction of net worth, even for the median household, than Table 2.1 suggests. Second, because both IRAs and 401(k)s are relatively recent financial innovations and because there are contribution limits presenting very wealthy households from developing large balances in these accounts, the total assets in these accounts still represent a small share of total household net worth. In 1989, for example, the total balance in IRAs and 
Keogh plans was $\$ 501.7$ billion, and that in 401(k) plans was approximately $\$ 357$ billion. ${ }^{9}$ This corresponds to roughly 5.3 percent of total household sector net worth.

\section{Retirement Saving Contributions and Saving Behavior}

The data presented in Figure 1.2 above show that from there widespread introduction in 1982 until the Tax Reform Act of 1986 contributions to IRAs were a substantial share of the flow of personal saving in the United States; 401(k) contributions are an increasingly important share. This observation alone does not imply that such retirement saving plans have increased personal saving. Resolving this issue requires information on how the other components of private saving respond to changes in saving through targeted retirement programs. Because much of the variation in IRA and $401(\mathrm{k})$ availability and contribution levels is over time, there is a temptation to examine the overall level of private saving before and after these programs became available. Many factors besides the availability of these programs affect the level of private saving, however, so such time series comparisons can be unreliable.

Studying the net saving effects of these programs using household-level data is also subject to a number of difficulties. It is tempting to compare the levels and growth

${ }^{9}$ The value of IRAs and Keogh accounts is drawn from the Employee Benefit Research Institute, Issue Brief 119, 1991. The value of 401(k) plan assets is from the Private Pension Plan Bulletin 1993, Table E19. 
rates of financial assets for households that do and do not participate in retirement saving programs. A key problem in interpreting such cross-sectional comparisons is the heterogeneity in saving behavior among individuals. Some people save and others don't, and the savers tend to save more in all forms. For example, families with IRA accounts have larger financial asset balances than families without IRAs. But this does not necessarily mean that IRAs explain the difference.

An accumulating body of evidence, however, suggests that contributions to IRAs and 401(k) plans represent new saving. For example, Venti and Wise [1990, 1991], based on the U.S. Consumer Expenditure Surveys and the Survey of Income and Program Participation find no evidence that saving rates in non-IRA channels are lower for households that were accumulating IRA balances in the early 1980 s than non-IRA households, who were demographically similar and had comparable prior saving behavior. These estimates imply that increases in the IRA limits would lead to substantial increases in IRA saving and very little reduction in other saving. If the IRA limit were raised, the estimates imply that one-half to two-thirds of the increase in IRA saving would be funded by a decrease in current consumption and about one-third by reduced taxes. Only a small share of the IRA contributions, at most 20 percent, would come from reductions in other saving. ${ }^{10}$

\footnotetext{
${ }^{10}$ Results using different data sets and different methodologies are presented in Venti and Wise [1986, 1987]. These studies also find very little substitution of IRA for other personal financial asset
} 
With the availability of better data covering a longer time span, later-generation studies have used non-parametric methods to control for heterogeneity in individual saving behavior. The methods exploit quasi-experimental differences in household "exposure" to IRA or $401(\mathrm{k})$ saving opportunities to investigate the effect of these programs on household saving behavior. Venti and Wise [1992] consider the accumulation of IRA assets of successive random samples of IRA contributors who were exposed to the IRA option for increasing periods of time, but who were alike in other demographic respects. Their accumulation of IRA assets is compared to the change in non-IRA financial assets. While there was a large increase in IRA assets there was essentially no change in the level of other assets. Poterba, Venti, and Wise [1994, 1993] report results from two such quasi-experimental identification strategies. The first, like the Venti and Wise [1992] analysis, compares the assets accumulated by individuals of similar age and income but in different birth cohorts, and who have therefore been able to save through IRAs and 401(k) plans for different lengths of time. These analysis represent the first study of the saving effect of $401(\mathrm{k})$ plans. Data from the Survey of Income and Program Participation -- for 1984, 1987, and 1991 -- provide

saving. Gale and Scholz [1990] find essentially no net saving from IRAs. Feenberg and Skinner [1989], like Venti and Wise, find that IRA contributions represent new saving for the most part. Joines and Manegold [1991] conclude that about half of IRA contributions represent new saving. 
the basis for these comparisons. Evidence from the 1993 analysis is shown in Table 2.1 .

Since age, income, and other characteristics of the three cross-sections are similar, one would expect saving balances also to be similar. The different cohorts do face different historical patterns of asset retums, but for households with relatively little wealth, this should not have much effect on observed holdings. The critical differences between these cohorts, from the standpoint of retirement saving accounts, are that the 1984 sample had only about two years (1982 to 1984$)$ to accumulate $401(\mathrm{k})$ and IRA balances, while the 1987 sample had about five years, and the 1991 sample about nine years. The central question is whether longer "exposure" to IRAs, or 401(k)s, results in higher levels of saving.

The summary statistics in Table 2.1 provide important evidence on this issue. Non-IRA, non-401(k) assets do not appear to decline as either IRA and 401(k) assets increase. There were large increases between 1984 and 1991 in the total financial assets of families with both IRA and 401(k) accounts, but little change in their nonIRA-401(k) financial assets. There were also substantial increases in the total financial assets of families that had IRAs only or 401(k)s only, but no decline in their non-IRA or non-401(k) financial assets. It is difficult to argue that these differences are due to some form of unobserved heterogeneity across households in different cohorts. 
The growing importance of 401(k) plans provides a second "quasi-experimental" way to assess the net effect of retirement saving programs. Assuming that $401(\mathrm{k})$ eligibility is largely exogenous, the result of decisions by employers, then comparisons between non-401(k) asset accumulation of those who are and who are not eligible for such plans provides another way to assess their saving effects. This approach views 401(k) eligibility as the "treatment" in a "natural experiment" to evaluate the saving effect of a plan with the 401(k) tax incentives, employer payroll deductions, and other provisions. In this case the key question is whether families who were eligible for a 401(k)s in a given year had larger total financial asset balances than families who were not eligible, or, equivalently, did non-401(k) financial assets decline enough to offset the $401(\mathrm{k})$ contributions of eligible families?

Table 3.1 presents the results of this comparison using data from the 1987 and 1991 Surveys of Income and Program Participation. The values in the table are reported by income interval to control for income-related differences in 401(k) eligibility. It presents the median level of $401(\mathrm{k})$ assets, as well as the median for total financial assets.

If families reduced saving in other forms when they became eligible for a 401(k) plan, the typical family eligible for 401(k) in 1991 should have accumulated less wealth in other (non-401(k)) financial assets than the typical family who was not eligible for 
a 401(k). This is not the case. The median level of total financial assets of families with incomes above $\$ 75$ thousand, for example, who are eligible for a $401(\mathrm{k})$ is $\$ 52,500$, whereas the median for families who are not eligible is only $\$ 31,000$. There is little difference in the other financial assets of families who are and are not eligible for a 401(k). Indeed, the eligible families have somewhat higher levels of other financial assets. The data show no substitution of $401(\mathrm{k})$ contributions for other financial asset saving.

Figure 2.1 presents the information in Tables 2.1a and 2.1b, as well as separate data for the changing wealth holdings of households with both IRAs and 401(k)s. The figure shows that households with either or both personal retirement saving accounts experienced large increases in total financial assets but in no case was there substantial decumulation of other financial assets. And, thus no evidence of substitution of $401(\mathrm{k})$ and IRA saving for saving in other financial asset forms.

Poterba, Venti, and Wise [1994, 1993] also explore the interaction between IRA and $401(\mathrm{k})$ saving. Somewhat paradoxically, there is little apparent substitution between saving in these two tax-deferred vehicles. The data on individual saving patterns suggest a number of "economic" anomalies. For example, many households make IRA contributions even though they have not made the maximum allowable contribution to their $401(\mathrm{k})$ plans. Because of employer matching, 401(k) plans are 
typically more generous than IRAs. These results call into question standard assumptions about the determinants of saving and the degree to which different forms of saving are treated as close substitutes.

\section{Personal Saving Trends and Contributions to IRAs and 401(k)s}

The decline of the aggregate personal saving rate in the United States during the last decade is poorly understood. While a number of studies, including Summers and Carroll (1987) and Bosworth, Burtless, and Sabelhaus (1991), have tried to link this decline to demographic change, revisions in the structure of social insurance programs, increased household wealth, and other changes in the financial environment, they have failed to identify any single factor, or set of factors, that can explain the decline. The decline in personal saving is particularly surprising in light of the evidence presented above on the growth in IRAs and 401(k)s during the 1980s.

\subsection{The Measurement of Aggregate Personal Saving}

There are two widely-cited measures of personal saving: the National Income and Product Accounts (NIPA), and the Federal Reserve Board Flow of Funds (FOF) measure. These two measures differ both in conceptual intent and in the data on which they are based. The NIPA personal saving measure is intended to reflect the difference between personal disposable income and personal spending. The Flow of Funds saving 
measure, in contrast, is intended to reflect the change in net financial assets and liabilities between two points in time, plus net household investment in tangible assets. The two most important categories of tangible assets are consumer durables, primarily automobiles, and owner-occupied housing. Because each of these measures of personal saving is computed from large and sometimes offsetting gross flows, measurement errors in income, spending, or asset flows are reflected in the reported saving flows.

The levels of the NIPA and Flow of Funds (FOF) saving measures sometimes differ by several hundred billion dollars. The FOF measure was more than twice the share of personal disposable income as the NIPA measure in the late 1980s. To illustrate conceptual differences in what the measures attempt to capture, as well as the differences in the data that underlie the measures, it is helpful to consider a saving concept that is intermediate between the FOF and NIPA: the NIPA saving concept computed using Flow of Funds data. This saving flow, which is also published by the Federal Reserve Board, equals the FOF saving flow less three components: net household investment in consumer durables, the change in the insurance and pension reserves of federal and state and local governments, and the net saving of corporate farms. The first two adjustments are much larger than the third. In 1990, for example, net investment in consumer durables equalled $\$ 85.1$ billion, and the change in 
government insurance liabilities was $\$ 88$ billion. The government insurance and pension reserve adjustment consists of the change in the financial reserves of three federal retirement programs -- veterans, railroad employees, and other federal workers -- plus the change in the reserves of state and local government retirement funds. ${ }^{11}$ After making these three adjustments to the Flow of Funds personal saving flow, the resulting series (which we call FOF NIPA Basis) and NIPA series are conceptually the same and in principle are measuring the same thing. Differences remain, however, in the way the same saving concept is measured in the two series. The Flow of Funds estimate of personal saving begins with financial securities transactions, like net purchases of saving bonds and corporate stock, and net deposits to various financial intermediaries. These are added to the increase in private pension reserves, and the net acquisition of tangible assets. The latter is computed as gross purchases of various assets less an estimate of depreciation of existing holdings.

In contrast to the Flow of Funds estimate, the National Income and Product Accounts estimate of the saving rate is the difference between personal disposable income and personal outlays. Several features of the NIPA measure are important. First, outlays include expenditures on all durable goods except owner-occupied

${ }^{11}$ The NIPA attribute the assets and liabilities of private pension plans to the household sector, but they do not perform a similar adjustment with government pension plans. This is the reason this adjustment is required. 
housing. While a newly purchased car is counted as consumption in the national income accounts, a new house is capitalized: personal income rises by an estimate of the imputed income the new homeowner receives from the house, and outlays rise by an estimate of the rental cost of the house. Second, the NIPA personal income estimate includes a number of imputations for income that households never receive as cash. These include the interest and dividends received by private employer-provided pension funds, the estimated market value of in-kind transfers such as Medicare, and the differential between the interest earned and paid by financial intermediaries (labelled "imputed interest income"). These imputations lead to potentially large differences between actual personal saving on a cash basis, the type of saving that IRAs and 401(k)s may have encouraged, and NIPA reported personal saving. ${ }^{12}$

Both the NIPA and Flow of Funds measures include directly employer contributions to 401(k) plans. In the NIPA, these show up as other labor income, one of the components of personal disposable income. In the Flow of Funds, these are additions to the reserves of private insured and non-insured pension funds. The Flow of Funds accounts also include individual contributions to these plans, but the NIPA does not include such contributions directly; they are part of the residual between

${ }^{12}$ Bosworth, Burtless, and Sabelhaus (1991, p.228) present a calculation of cash basis saving in an appendix to their paper. While the saving rate computed on a cash basis is the same as that on a NIPA basis for 1989, there is no reason to expect such strong agreement in general. There are numerous required adjustments to the NIPA saving flow. 
income and outlays. A similar situation applies to IRA contributions: they do not directly enter the NIPA calculation, although they directly enter the Flow of Funds calculation when individuals add to IRAs.

\subsection{Trends in Aggregate Personal Saving}

Table 4.1 reports the time series for both the NIPA and FOF personal saving rates for the 1956-1992 period. The two measures display substantially different levels, with the FOF measure between five and eight percent higher than the NIPA measure during the 1980s. The two measures of personal saving also show very different trends during the 1980s, as shown in Figure 4.1. The NIPA measure fell almost 50 percent over the 80 s, declining more or less continuously from around 8 percent in 1980 to 4 percent in 1990, with the most precipitous decline after 1984. In contrast, the FOF measure rose from 11 percent in 1980 to 14 percent in 1986 -- the period over which IRAs expanded -- and then declined to around 10 percent, ending the decade about 10 percent below its starting value (as opposed to the 50 percent decline in the NIPA measure). The FOF NIPA Basis measure remained relatively constant at around 8 percent until 1986 and then fell to 5 percent, ending the decade at 6 percent. An apparent agreement over all the measures is a sharp decline in the saving rate following the Tax Reform Act of 1986, when IRA contributions plummeted. 
Although the measures differ in important respects, when compared as a group to the growth in total contributions to IRAs and 401(k) plans reported in Figure 1.1, it may be surprising that national personal saving was not higher at the end than at the beginning of the decade.

To place the national personal saving flows in perspective with respect to targeted saving contributions, Table 4.2 reports the annual flow of national personal saving for each year beginning in 1956 . We emphasize the data for the 1980s. The flow of national personal saving based on the two FOF and the NIPA measures is shown in Figure 4.2 together with the total of contributions to retirement saving plans, reported in Figure 1.2. It is evident that retirement saving contributions represent a large fraction of national personal saving. In addition, it is evident that the FOF measures show an increase in other personal saving at the same time that contributions to personal retirement plans were increasing rapidly. The national series also show a sharp drop after the Tax Reform Act of 1986 and the subsequent fall in IRA contributions. Possibly most striking is that while total retirement contributions declined as a proportion of FOF national saving over the 1980 s, retirement contributions increased as a percent of NIPA saving. Indeed, by 1989 retirement contributions represented 80 percent of NIPA saving. We question whether this number is believable 
and suggest that it brings into question the validity of the most widely cited measure of national saving.

The individual components of retirement saving relative to national saving are also striking. Recall that in their peak year (1985) IRA contributions totalled \$39 billion. Personal saving measured on a Flow of Funds basis was $\$ 361.1$ billion, and on a NIPA basis, $\$ 189$ billion. The NIPA saving rate was 6.4 percent of disposable income, so the flow of IRA contributions equalled 1.3 percent of disposable income. In more recent years, the flow of $401(\mathrm{k})$ contributions has been a larger share of the reported saving flow. In 1990, for example, we estimate that $401(\mathrm{k})$ contributions were approximately $\$ 60$ billion. These contributions were roughly one third as large as the total personal saving flow estimate from the NIPA (\$176.5), and slightly under one sixth of the FOF personal saving estimate ( $\$ 417$ billion). If the amount that individuals and their firms contributed to $401(\mathrm{k})$ accounts in 1990 had been channelled to consumption rather than saving, the NIPA personal saving rate would have been less than 3 percent of disposable income.

An apparently important factor in the decline of the personal saving rate during the last ten years, is the decline in contributions to employer-provided pension plans. Although contributions to defined contribution plans remained constant over the period, 
defined benefit plan contributions fell substantially. Contributions to these plans together fell from 3.5 percent of disposable income in 1981 to 1.4 percent in 1989.

This example demonstrates clearly that the personal saving rate as usually reported includes some components beyond household control, and suggests that future research on the source of declining saving should focus on the imputations and other factors that make personal saving in the NIPA and Flow of Funds different from cash saving. Another approach to measuring saving trends is to construct a time series of saving rates from household surveys. There is some evidence from household surveys, presented in Bosworth, Burtless, and Sabelhaus (1991), that personal cash saving has declined since the mid-1960s. This work does not bear on the timing, magnitude, or source of the personal saving decline in the late 1980s, however.

\section{$\underline{\text { 5. Conclusions }}$}

Individual saving through targeted retirement saving accounts -- IRAs and 401(k)s in particular -- grew rapidly during the 1980 s. While aggregate measures of personal saving show a sharp decline in the late 1980s, following the Tax Reform Act of 1986 and the fall in IRA saving, the 401(k) component of saving was rising, forestalling what could have been an even sharper decline in personal saving. Contributions to targeted saving accounts currently account for approximately one third of the flow of personal saving measured in the National Income and Product Accounts. 
Studies of asset accumulation patterns for those who do, and do not, contribute to these plans suggests very little substitution between saving in these plans and other forms of personal saving. This suggests that most of the contributions to these plans represent saving that would not otherwise have occurred.

In a stable economic and tax environment, contributions to IRAs and 401(k)s appear strongly persistent from year to year. If current contribution patterns persist, the accumulation of assets in these accounts will represent a very important component of wealth at retirement for those who reach retirement in the early 21 st century. Unlike other traditional forms of retirement income provision, such as Social Security or defined-benefit pension plans, individuals make portfolio decisions about their investments in targeted accounts. This may introduce more heterogeneity into the distribution of wealth at retirement, as there may be greater variation in the returns that individuals earn on their retirement investments. On the other hand, contributions to personal retirement plans are likely to be much more equally distributed than other forms of personal financial asset saving. 


\section{References}

Andrews, Emily S., 1992, "The Growth and Distribution of 401(k) Plans," in J. Turner and D. Beller, eds., Trends in Pensions 1992 (Washington: U.S. Department of Labor).

Beller, Daniel J. and Helen H. Lawrence, 1992, "Trends in Private Pension Plan Coverage," in John A. Turner and Daniel J. Beller, Trends in Pensions 1992 (Washington: U.S. Government Printing Office, 1992).

Bernheim, B. Douglas, and John B. Shoven, 1988, "Pension Funding and Saving," in Z. Bodie, J. Shoven, and D. Wise, eds., Pensions in the U.S. Economy (Chicago: University of Chicago Press).

Bosworth, Barry, Gary Burtless, and John Sabelhaus, 1991, "The Decline in Saving: Evidence from Household Surveys," Brookings Papers on Economic Activity 1991:1, 183-241.

Holloway, Thomas M., 1989, "Present NIPA Saving Measures: Their Characteristics and Limitations," in Robert E. Lipsey and Helen S. Tice, eds., The Measurement of Saving, Investment, and Wealth (Chicago: University of Chicago Press), 21100.

Papke, Leslie, 1992, "Participation in and Contributions to 401(k) Plans: Evidence from Plan Data," NBER Working Paper 4199. 
Poterba, James M., Steven F. Venti, and David Wise, 1994, "401(k) Plans and TaxDeferred Saving," in D. Wise, ed., Studies in the Economics of Aging (Chicago: University of Chicago Press).

Poterba, James M., Steven F. Venti, and David Wise, 1993, "Do 401(k) Contributions Crowd Out Other Personal Saving?" forthcoming in Journal of Public Economics.

Schieber, Sylvester and John Shoven. 1993. "The Consequences of Population Aging on Private Pension Fund Saving and Asset Markets," unpublished, September 1993.

Shefrin, Steven and Richard Thaler, 1988, "The Behavioral Life Cycle Hypothesis," Economic Inquiry 26: 609-643.

Summers, Lawrence, and Chris Carroll, 1987, "Why is U.S. National Saving so Low?," Brookings Papers on Economic Activity 1987:2, 607-635.

U.S. General Accounting Office, 1988a, 401(k) Plans: Incidence, Provisions, and Benefits (Washington: General Accounting Office).

U.S. General Accounting Office, 1988b, 401(k) Plans: Participation and Deferral Rates by Plan Features and Other Information (Washington: General Accounting Office). 
U.S. Department of Labor. 1993. "Abstract of 1989 Form 5500 Annual Reports." Private Pension Plan Bulletin, No. 1, Winter.

Venti, Steven F. and David A. Wise. 1986. "Tax-Deferred Accounts, Constrained Choice and Estimation of Individual Saving." Review of Economic Studies 53: $579-601$.

Venti, Steven F. and David A. Wise. 1987. "IRAs and Saving," in M. Feldstein (ed.), The Effects of Taxation on Capital Accumulation. Chicago: University of Chicago Press.

Venti, Steven F., and David A. Wise. 1990. "Have IRAs Increased U.S. Saving?: Evidence from the Consumer Expenditure Surveys." Quarterly Journal of Economics 105:661-698.

Venti, Steven F., and David A. Wise. 1991. "The Saving Effect of Tax-Deferred Retirement Accounts: Evidence from SIPP," in B. Douglas Bernheim and John Shoven, eds., National Saving and Economic Performance (Chicago: University of Chicago Press), 103-131.

Venti, Steven F., and David A. Wise. 1992. "Government Policy and Personal Retirement Saving," in J. Poterba, ed., Tax Policy and the Economy, volume 6 (Cambridge: MIT Press) 1-41. 
Wilson, John F., James L. Freund, Frederick O. Yohn, Jr., and Walther Lederer, 1989, "Measuring Household Saving: Recent Experience from a Flow of Funds Perspective," in Robert E. Lipsey and Helen S. Tice, eds., The Measurement of Saving. Investment, and Wealth (Chicago: University of Chicago Press), 101152. 


\begin{tabular}{||lcc||}
\hline \multicolumn{4}{|c|}{$\begin{array}{c}\text { Table 1.1: } \\
\text { Number of Tax Returns Claiming IRA } \\
\text { Contributions, 1980-1990 }\end{array}$} \\
\hline \multicolumn{4}{|c|}{$\begin{array}{c}\text { Number of IRA } \\
\text { Contributor Returns }\end{array}$} & $\begin{array}{c}\text { Total IRA } \\
\text { Contributions }\end{array}$ \\
\hline 1980 & & \\
1981 & 2.564 & 3.431 \\
1982 & 3.415 & 4.750 \\
1983 & 12.010 & 28.274 \\
1984 & 13.613 & 32.061 \\
1985 & 15.232 & 35.374 \\
1986 & 16.205 & 38.211 \\
1987 & 15.535 & 37.758 \\
1988 & 7.318 & 14.065 \\
1989 & 6.361 & 11.882 \\
1990 & 5.882 & 10.960 \\
& 4.785 & 9.928 \\
Source: & U.S. Department of the Treasury, Statistics of Income: \\
Individual Tax Returns (various issues). Entries in the first column are in \\
millions of tax returns; the second column represents billions of dollars. \\
\hline \hline
\end{tabular}




\begin{tabular}{||lccc||}
\hline \multicolumn{4}{|c|}{ Table 1.2: Growth of 401(k) Plans } \\
\hline Year & $\begin{array}{c}\text { Plans } \\
\text { (thousands) }\end{array}$ & $\begin{array}{c}\text { Participants } \\
\text { (millions) }\end{array}$ & $\begin{array}{c}\text { Contributions } \\
\text { (billions of \$'s) }\end{array}$ \\
\hline \multicolumn{4}{|c||}{} \\
1983 & 1.7 & 4.4 & n.a. \\
1984 & 17.3 & 7.5 & 16.3 \\
1985 & 29.9 & 10.3 & 24.3 \\
1986 & 37.4 & 11.6 & 29.2 \\
1987 & 45.1 & 13.1 & 33.2 \\
1988 & 68.1 & 15.5 & 39.4 \\
1989 & 83.3 & 17.3 & 46.1 \\
& \\
Note: Data through 1988 from Table A4 in Trends in Pensions 1992. 1989 data \\
from Table E19 of Private Pension Plan Bulletin, 1993.
\end{tabular}




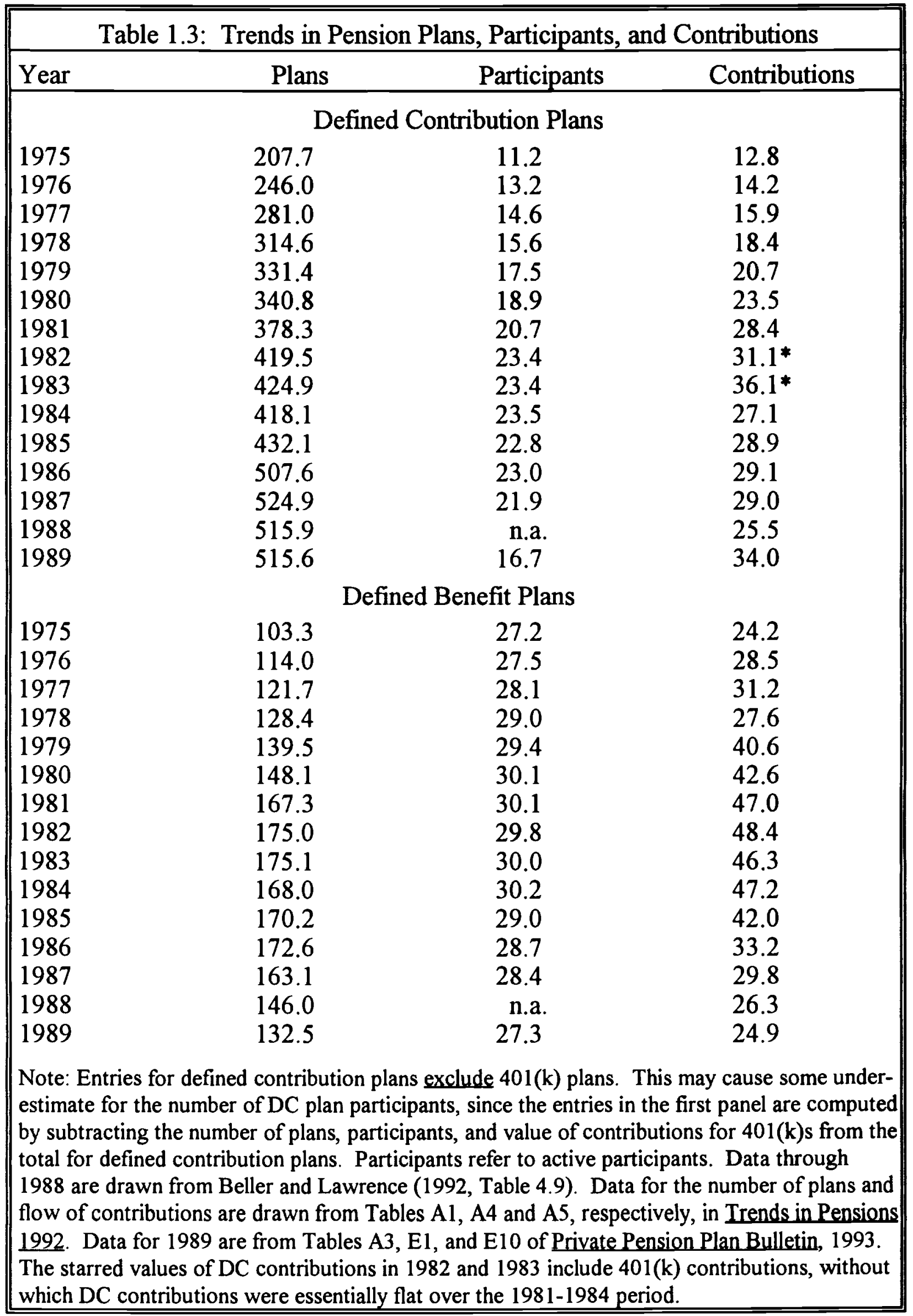




\begin{tabular}{|c|c|c|c|c|}
\hline \multicolumn{5}{|c|}{$\begin{array}{l}\text { Table 1.4: Eligibility and Participation for Selected Years: } 401(\mathrm{k}) \text { and IRA } \\
\text { Compared }\end{array}$} \\
\hline & $\begin{array}{l}\text { Percent } \\
\text { Eligible for } \\
\text { a 401(k) }\end{array}$ & $\begin{array}{c}\text { Percent } 401(\mathrm{k}) \\
\text { Participation } \\
\text { Given Eligibility }\end{array}$ & $\begin{array}{c}\text { Percent } \\
401(k) \\
\text { Participation }\end{array}$ & $\begin{array}{l}\text { Percent with } \\
\text { IRA Account }\end{array}$ \\
\hline 1984 & 13.3 & 58.1 & 7.7 & 25.4 \\
\hline 1987 & 20.0 & 62.6 & 12.5 & 28.8 \\
\hline 1991 & 34.7 & 70.8 & 24.6 & 27.1 \\
\hline
\end{tabular}




\begin{tabular}{|c|c|c|c|c|c|c|c|c|}
\hline \multirow[b]{2}{*}{ Age } & \multicolumn{8}{|c|}{ Income } \\
\hline & $<10$ & $10-20$ & $20-30$ & $30-40$ & $40-50$ & $50-75$ & $>75$ & All \\
\hline \multicolumn{9}{|c|}{ Percent Eligible for a 401(k) } \\
\hline $\begin{array}{l}25-35 \\
35-45 \\
45-55 \\
55-65 \\
\text { All }\end{array}$ & $\begin{array}{r}5.1 \\
11.2 \\
2.1 \\
7.9 \\
6.4\end{array}$ & $\begin{array}{l}14.8 \\
20.2 \\
16.5 \\
14.4 \\
16.6\end{array}$ & $\begin{array}{l}30.2 \\
34.6 \\
27.6 \\
20.9 \\
29.7\end{array}$ & $\begin{array}{l}40.1 \\
42.8 \\
32.8 \\
36.5 \\
39.0\end{array}$ & $\begin{array}{l}38.9 \\
46.0 \\
48.7 \\
37.7 \\
43.7\end{array}$ & $\begin{array}{l}51.3 \\
53.9 \\
56.4 \\
51.9 \\
53.8\end{array}$ & $\begin{array}{l}51.2 \\
47.1 \\
52.5 \\
37.0 \\
48.1\end{array}$ & $\begin{array}{l}31.4 \\
39.2 \\
35.9 \\
28.9 \\
34.7\end{array}$ \\
\hline \multicolumn{9}{|c|}{ Percent 401(k) Participation Given Eligibility } \\
\hline $\begin{array}{l}25-35 \\
35-45 \\
45-55 \\
55-65 \\
\text { All }\end{array}$ & $\begin{array}{l}79.8 \\
58.4 \\
72.5 \\
85.2 \\
70.8\end{array}$ & $\begin{array}{l}63.2 \\
67.7 \\
51.5 \\
68.3 \\
63.0\end{array}$ & $\begin{array}{l}70.3 \\
59.8 \\
57.6 \\
49.0 \\
61.7\end{array}$ & $\begin{array}{l}74.1 \\
63.7 \\
58.5 \\
72.5 \\
67.3\end{array}$ & $\begin{array}{l}73.8 \\
68.7 \\
81.6 \\
67.8 \\
72.9\end{array}$ & $\begin{array}{l}76.1 \\
67.2 \\
75.1 \\
84.0 \\
73.3\end{array}$ & $\begin{array}{l}86.2 \\
83.8 \\
88.1 \\
85.7 \\
85.8\end{array}$ & $\begin{array}{l}73.5 \\
67.7 \\
72.3 \\
72.3 \\
70.8\end{array}$ \\
\hline \multicolumn{9}{|c|}{ Percent 401(k) Participation } \\
\hline $\begin{array}{l}25-35 \\
35-45 \\
45-55 \\
55-65 \\
\text { All }\end{array}$ & $\begin{array}{l}4.1 \\
6.6 \\
1.5 \\
6.7 \\
4.5\end{array}$ & $\begin{array}{r}9.4 \\
13.6 \\
8.5 \\
9.8 \\
10.5\end{array}$ & $\begin{array}{l}21.2 \\
20.7 \\
15.9 \\
10.2 \\
18.4\end{array}$ & $\begin{array}{l}29.7 \\
27.3 \\
19.2 \\
26.5 \\
26.2\end{array}$ & $\begin{array}{l}28.7 \\
31.6 \\
39.8 \\
25.6 \\
31.8\end{array}$ & $\begin{array}{l}39.1 \\
36.3 \\
42.3 \\
43.6 \\
39.4\end{array}$ & $\begin{array}{l}44.2 \\
39.5 \\
46.3 \\
31.7 \\
41.3\end{array}$ & $\begin{array}{l}23.0 \\
26.5 \\
25.9 \\
20.9 \\
24.6\end{array}$ \\
\hline \multicolumn{9}{|c|}{ Percent with IRA Account } \\
\hline $\begin{array}{l}25-35 \\
35-45 \\
45-55 \\
55-65 \\
\text { All }\end{array}$ & $\begin{array}{r}3.8 \\
10.1 \\
6.0 \\
14.8 \\
7.9 \\
\end{array}$ & $\begin{array}{r}4.8 \\
6.8 \\
12.9 \\
24.1 \\
9.7\end{array}$ & $\begin{array}{r}9.3 \\
15.4 \\
24.9 \\
37.6 \\
18.6\end{array}$ & $\begin{array}{l}14.8 \\
20.0 \\
31.3 \\
45.7 \\
24.7\end{array}$ & $\begin{array}{l}17.9 \\
33.0 \\
47.3 \\
59.5 \\
35.6\end{array}$ & $\begin{array}{l}23.6 \\
38.7 \\
50.2 \\
63.4 \\
41.1\end{array}$ & $\begin{array}{l}43.2 \\
59.9 \\
66.3 \\
75.5 \\
61.6\end{array}$ & $\begin{array}{l}13.2 \\
26.3 \\
35.3 \\
43.8 \\
27.1\end{array}$ \\
\hline
\end{tabular}




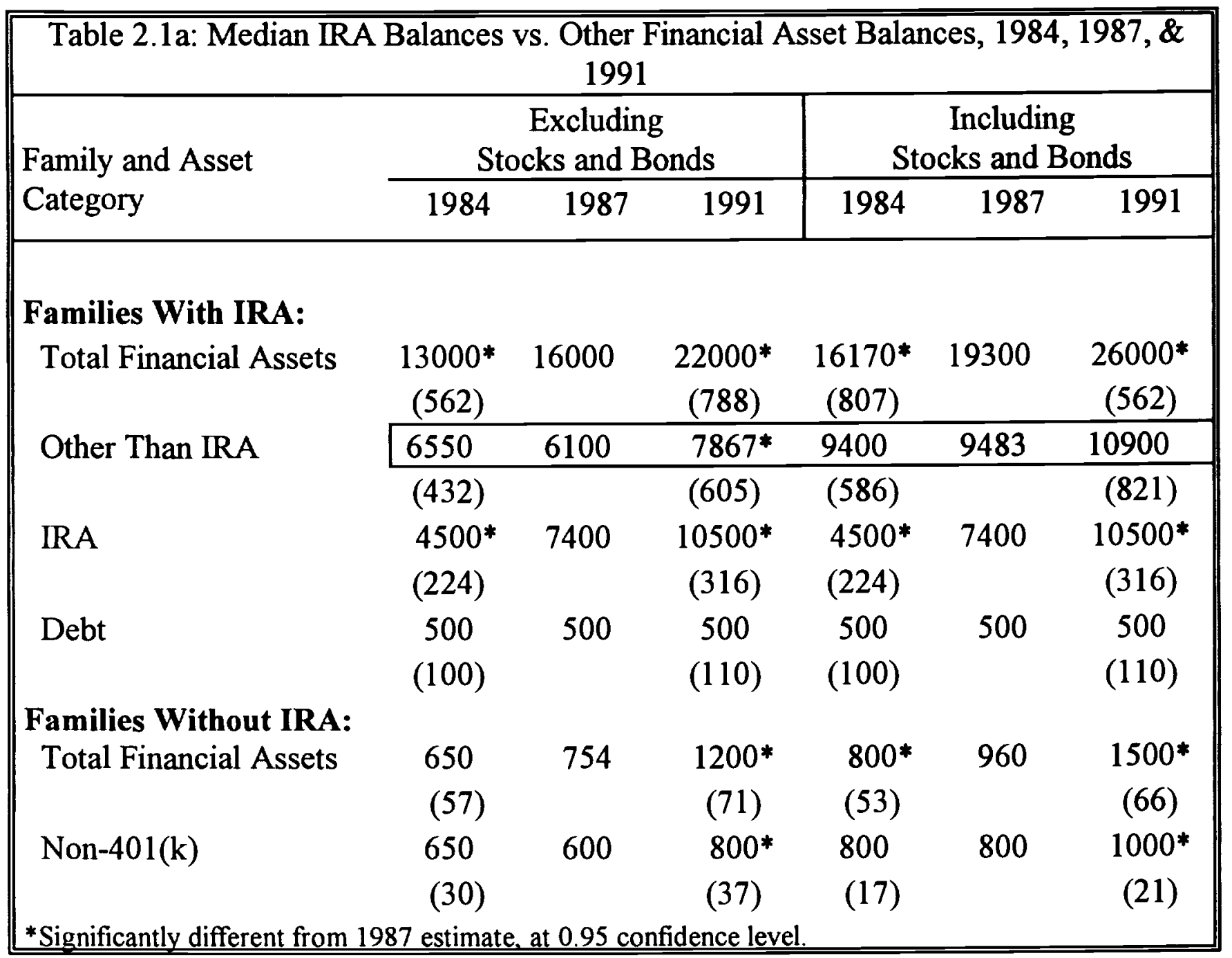




\begin{tabular}{|c|c|c|c|c|c|c|}
\hline \multirow[t]{2}{*}{ Family and Asset Category } & \multicolumn{3}{|c|}{$\begin{array}{c}\text { Excluding } \\
\text { Stocks and Bonds }\end{array}$} & \multicolumn{3}{|c|}{$\begin{array}{c}\text { Including } \\
\text { Stocks and Bonds }\end{array}$} \\
\hline & 1984 & 1987 & 1991 & 1984 & 1987 & 1991 \\
\hline $\begin{array}{l}\text { Families With 401(k): } \\
\text { Total Financial Assets }\end{array}$ & -- & 6061 & $\begin{array}{l}8858^{*} \\
(765)\end{array}$ & -- & 7299 & $\begin{array}{c}10449^{*} \\
(585)\end{array}$ \\
\hline Other Than $401(\mathrm{k})$ or IRA & 1800 & 1500 & 1500 & $3000 *$ & 2149 & 2209 \\
\hline & $(243)$ & & $(150)$ & $(229)$ & & $(370)$ \\
\hline $401(\mathrm{k})$ & -- & 2800 & $\begin{array}{l}4560^{*} \\
(349)\end{array}$ & -- & 2800 & $\begin{array}{l}4560^{*} \\
(349)\end{array}$ \\
\hline Debt & $\begin{array}{l}1000 \\
(220)\end{array}$ & 1200 & $\begin{array}{l}1500 \\
(189)\end{array}$ & $\begin{array}{l}1000 \\
(220)\end{array}$ & 1200 & $\begin{array}{l}1500 \\
(189)\end{array}$ \\
\hline $\begin{array}{l}\text { Families Without 401(k): } \\
\text { Total Financial Assets }\end{array}$ & $\begin{array}{r}1500 \\
(64)\end{array}$ & 1500 & $\begin{array}{l}1500 \\
(86)\end{array}$ & $\begin{array}{r}1949 \\
(87)\end{array}$ & 2000 & $\begin{array}{l}2000 \\
(116)\end{array}$ \\
\hline Non-IRA & $\begin{array}{r}1000 \\
(58)\end{array}$ & 1050 & $\begin{array}{r}1150 \\
(78)\end{array}$ & $\begin{array}{r}1400 \\
(87)\end{array}$ & 1430 & $\begin{array}{l}1500 \\
(116)\end{array}$ \\
\hline
\end{tabular}




\begin{tabular}{|c|c|c|c|c|c|c|c|}
\hline \multirow{2}{*}{$\begin{array}{l}\text { Asset Category and } \\
\text { Eligibility Status } \\
\end{array}$} & \multicolumn{7}{|c|}{ Income } \\
\hline & $<10$ & $10-20$ & $20-30$ & $30-40$ & $40-50$ & $50-75$ & $>75$ \\
\hline \multicolumn{8}{|l|}{ Results for 1991: } \\
\hline \multicolumn{8}{|l|}{ Total Financial Assets } \\
\hline Eligible for a $401(\mathrm{k})$ & $1499^{*}$ & $2800^{*}$ & $4608^{*}$ & $8649^{*}$ & $15005^{*}$ & $26000^{*}$ & $52500^{*}$ \\
\hline Not eligible for a $401(k)$ & 30 & 350 & 1124 & 2260 & 5600 & 10675 & 31000 \\
\hline \multicolumn{8}{|l|}{ Non-401(k)-IRA Assets } \\
\hline Eligible for a $401(\mathrm{k})$ & 300 & 500 & 1099 & $2550^{*}$ & $5000^{*}$ & $8839 *$ & 18100 \\
\hline Not eligible for a $401(k)$ & 20 & 310 & 1000 & 1750 & 4000 & 5800 & 18000 \\
\hline \multicolumn{8}{|l|}{ Results for 1987: } \\
\hline \multicolumn{8}{|l|}{ Total Financial Assets } \\
\hline Eligible for a $401(\mathrm{k})$ & $1090^{*}$ & $1190^{*}$ & $4000^{*}$ & $9205^{*}$ & $12650^{*}$ & $25343^{*}$ & $58119^{*}$ \\
\hline Not eligible for a $401(k)$ & 22 & 400 & 1366 & 4000 & 6630 & 14650 & 30900 \\
\hline \multicolumn{8}{|l|}{ Non-401(k)-IRA Assets } \\
\hline Eligible for a $401(\mathrm{k})$ & 361 & 305 & $1250^{*}$ & $3250^{*}$ & $5800^{*}$ & $11200^{*}$ & $25500^{*}$ \\
\hline Not eligible for a $401(\mathrm{k})$ & 20 & 350 & 1052 & 2800 & 4245 & 8737 & 21200 \\
\hline
\end{tabular}




\begin{tabular}{|c|c|c|c|}
\hline \multicolumn{4}{|c|}{ "Table 4.1: Personal Saving Rate, 1956-1992 } \\
\hline & $\begin{array}{l}\text { National Income } \\
\text { \& Product Accounts }\end{array}$ & Flow of Funds & $\begin{array}{c}\text { Flow of Funds } \\
\text { Data (NIPA Basis) }\end{array}$ \\
\hline 1956 & 7.1 & 13.0 & 9.2 \\
\hline 1957 & 7.2 & 12.2 & 9.0 \\
\hline 1958 & 7.4 & 11.3 & 9.3 \\
\hline 1959 & 6.3 & 10.4 & 7.4 \\
\hline 1960 & 5.7 & 10.6 & 7.7 \\
\hline 1961 & 6.6 & 10.1 & 8.0 \\
\hline 1962 & 6.5 & 11.2 & 8.1 \\
\hline 1963 & 5.9 & 11.7 & 8.0 \\
\hline 1964 & 6.9 & 13.4 & 9.1 \\
\hline 1965 & 7.0 & 13.9 & 8.8 \\
\hline 1966 & 6.8 & 15.5 & 10.1 \\
\hline 1967 & 8.1 & 14.8 & 10.1 \\
\hline 1968 & 7.1 & 13.3 & 8.0 \\
\hline 1969 & 6.5 & 12.3 & 7.3 \\
\hline 1970 & 8.0 & 12.6 & 8.7 \\
\hline 1971 & 8.3 & 13.2 & 8.7 \\
\hline 1972 & 7.0 & 14.3 & 8.8 \\
\hline 1973 & 9.0 & 16.4 & 10.9 \\
\hline 1974 & 8.9 & 11.7 & 7.7 \\
\hline 1975 & 8.7 & 13.5 & 9.7 \\
\hline 1976 & 7.4 & 13.3 & 8.6 \\
\hline 1977 & 6.3 & 13.9 & 8.5 \\
\hline 1978 & 6.9 & 13.0 & 7.6 \\
\hline 1979 & 7.0 & 12.2 & 7.9 \\
\hline 1980 & 7.9 & 11.0 & 7.8 \\
\hline 1981 & 8.8 & 11.0 & 7.9 \\
\hline 1982 & 8.6 & 11.3 & 8.4 \\
\hline 1983 & 6.8 & 12.5 & 8.3 \\
\hline 1984 & 8.0 & 13.9 & 8.6 \\
\hline 1985 & 6.4 & 12.3 & 6.5 \\
\hline 1986 & 6.0 & 14.0 & 7.9 \\
\hline 1987 & 4.3 & 10.3 & 4.9 \\
\hline 1988 & 4.4 & 10.7 & 5.1 \\
\hline 1989 & 4.0 & 12.1 & 6.7 \\
\hline 1990 & 4.3 & 10.3 & 6.0 \\
\hline 1991 & 4.7 & 8.7 & 5.8 \\
\hline 1992 & 4.8 & 9.6 & 6.3 \\
\hline
\end{tabular}




\begin{tabular}{|c|c|c|c|}
\hline & $\begin{array}{l}\text { National Income } \\
\text { \& Product Accounts }\end{array}$ & Flow of Funds & $\begin{array}{c}\text { Flow of Funds } \\
\text { Data (NIPA Basis) }\end{array}$ \\
\hline 1956 & 21.3 & 38.8 & 27.6 \\
\hline 1957 & 22.7 & 38.4 & 28.4 \\
\hline 1958 & 24.1 & 36.8 & 30.4 \\
\hline 1959 & 22.0 & 36.1 & 25.5 \\
\hline 1960 & 20.7 & 38.1 & 27.7 \\
\hline 1961 & 25.0 & 38.0 & 30.2 \\
\hline 1962 & 25.9 & 44.5 & 32.4 \\
\hline 1963 & 24.6 & 49.0 & 33.4 \\
\hline 1964 & 31.6 & 61.1 & 41.6 \\
\hline 1965 & 34.5 & 68.1 & 43.1 \\
\hline 1966 & 36.3 & 82.5 & 53.7 \\
\hline 1967 & 45.8 & 84.2 & 57.4 \\
\hline 1968 & 43.9 & 82.4 & 49.3 \\
\hline 1969 & 43.4 & 81.9 & 48.6 \\
\hline 1970 & 57.5 & 91.1 & 62.7 \\
\hline 1971 & 65.4 & 103.3 & 68.4 \\
\hline 1972 & 59.8 & 121.2 & 75.1 \\
\hline 1973 & 86.1 & 157.4 & 104.5 \\
\hline 1974 & 93.4 & 122.5 & 80.6 \\
\hline 1975 & 100.3 & 155.0 & 111.9 \\
\hline 1976 & 93.0 & 168.3 & 108.8 \\
\hline 1977 & 88.0 & 193.0 & 118.7 \\
\hline 1978 & 107.8 & 204.2 & 118.5 \\
\hline 1979 & 123.3 & 214.0 & 138.3 \\
\hline 1980 & 153.9 & 213.9 & 151.9 \\
\hline 1981 & 191.8 & 239.0 & 171.7 \\
\hline 1982 & 199.5 & 262.8 & 196.0 \\
\hline 1983 & 168.6 & 312.5 & 207.8 \\
\hline 1984 & 222.0 & 384.4 & 238.0 \\
\hline 1985 & 189.3 & 361.1 & 192.1 \\
\hline 1986 & 187.5 & 438.2 & 247.5 \\
\hline 1987 & 142.0 & 339.4 & 161.7 \\
\hline 1988 & 155.7 & 381.0 & 182.2 \\
\hline 1989 & 152.1 & 456.5 & 252.1 \\
\hline 1990 & 175.6 & 417.5 & 242.3 \\
\hline 1991 & 199.6 & 368.3 & 242.8 \\
\hline 1992 & 212.7 & 425.2 & 277.1 \\
\hline
\end{tabular}




\section{Figure 1.1 401(k) \& IRA Contributions In Billions, 1980 to 1990}

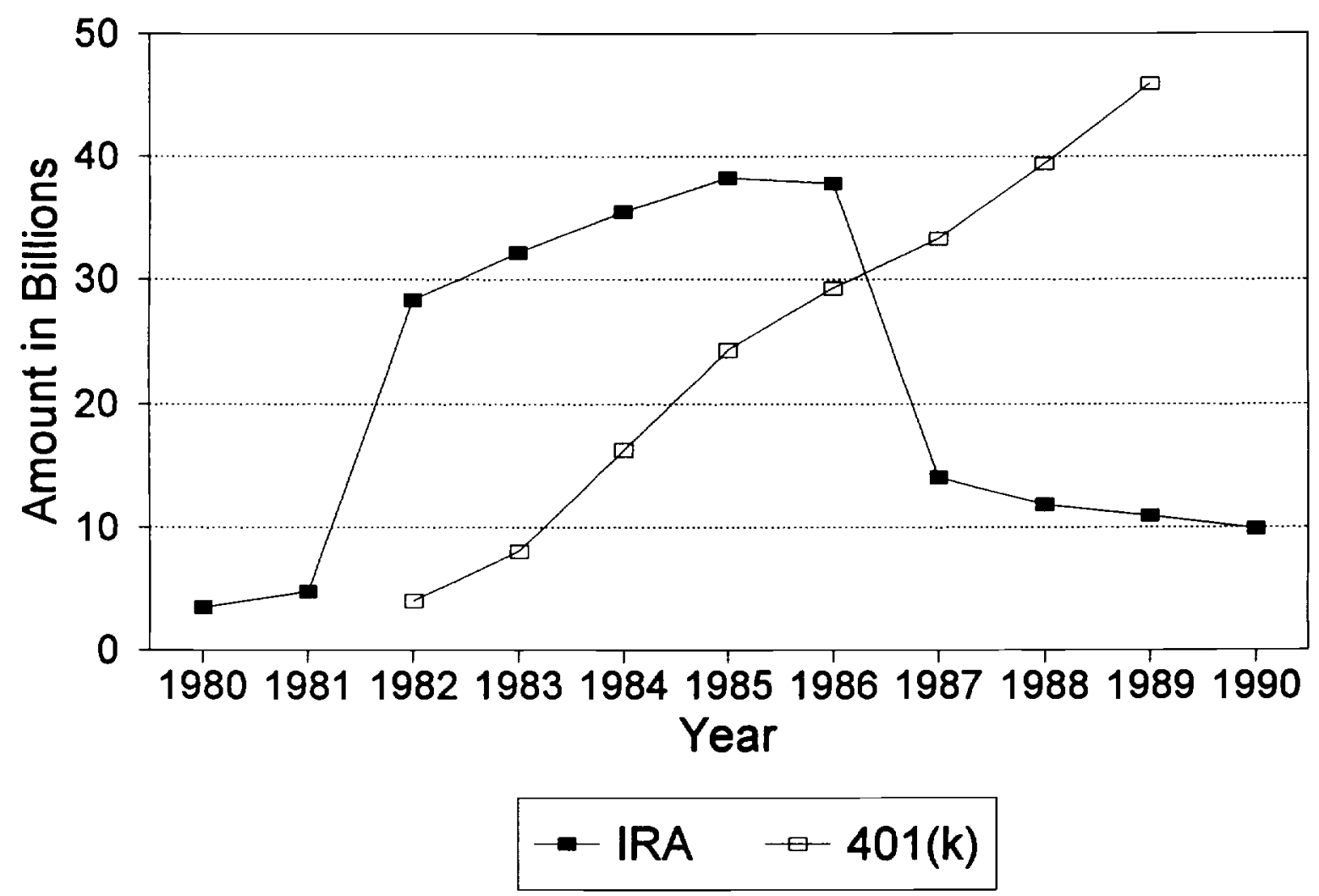


Figure 1.2 Retirement Saving

By Saving Plan, 1980 to 1988

(401(k) Estimated in 1982 \& 1983)

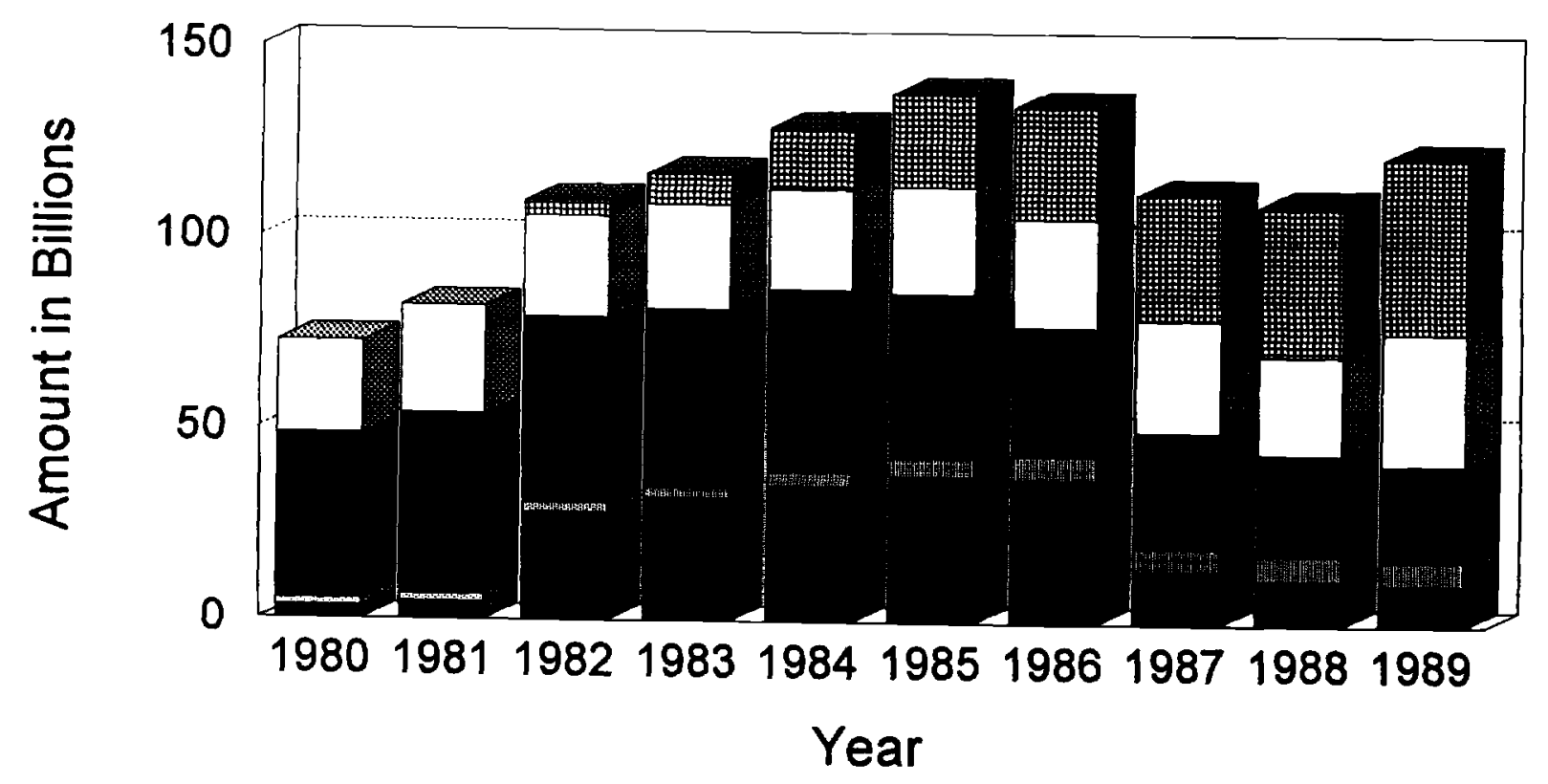

$\square$ IRA $\square$ Keogh $\square$ DB $\square$ DC 401(k) 


\section{Figure 2.1 Total and Other Assets By Saver Type}

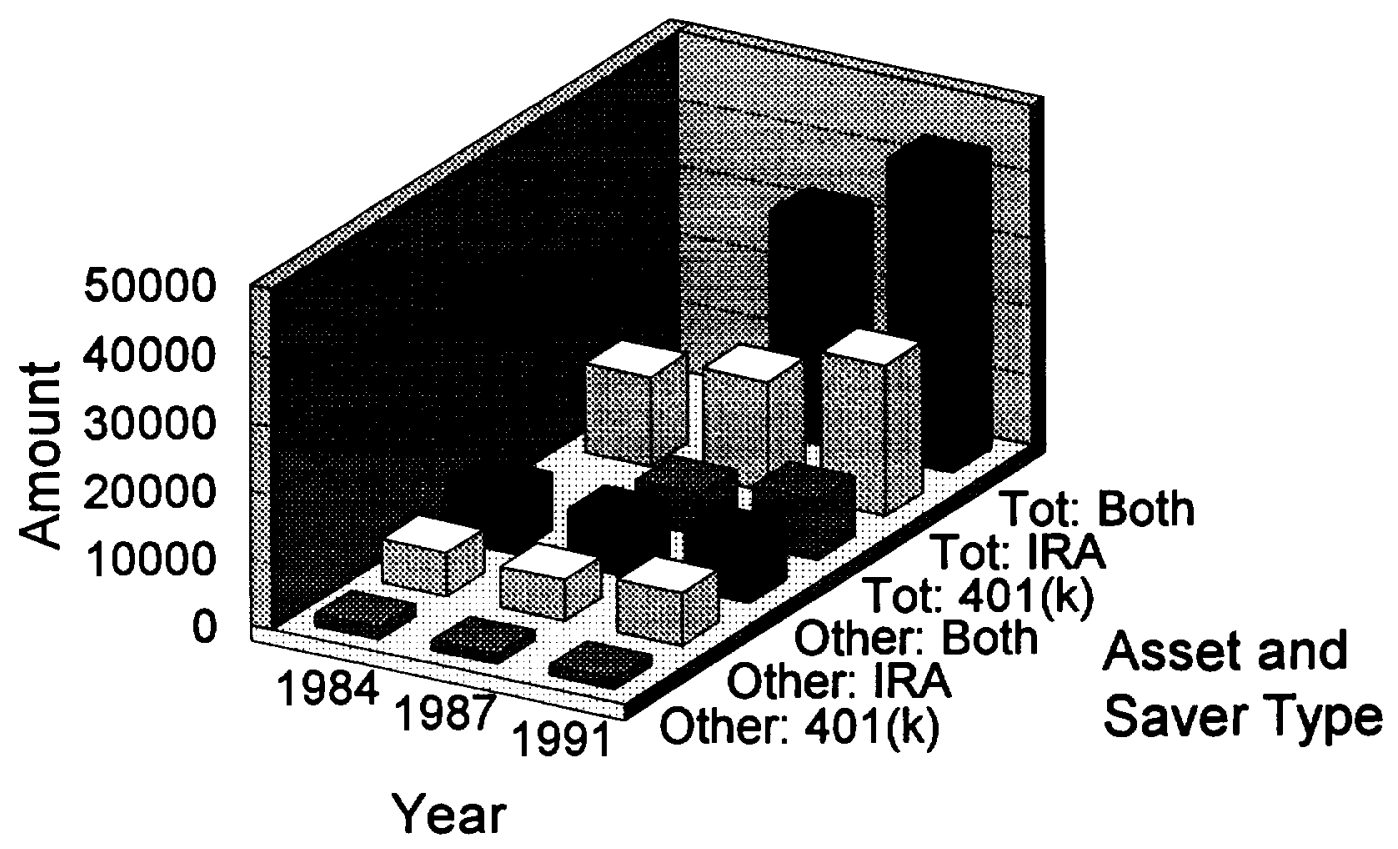

Families with both $401(\mathrm{k}) \mathrm{s}$ and IRAs had large increases in total financial assets but little change in other assets. Families with IRAs only or with 401(k)s only also had substantial increases in total financial assets but no decline in other fianancial assets. 
Fig 4.1. National Saving Rates

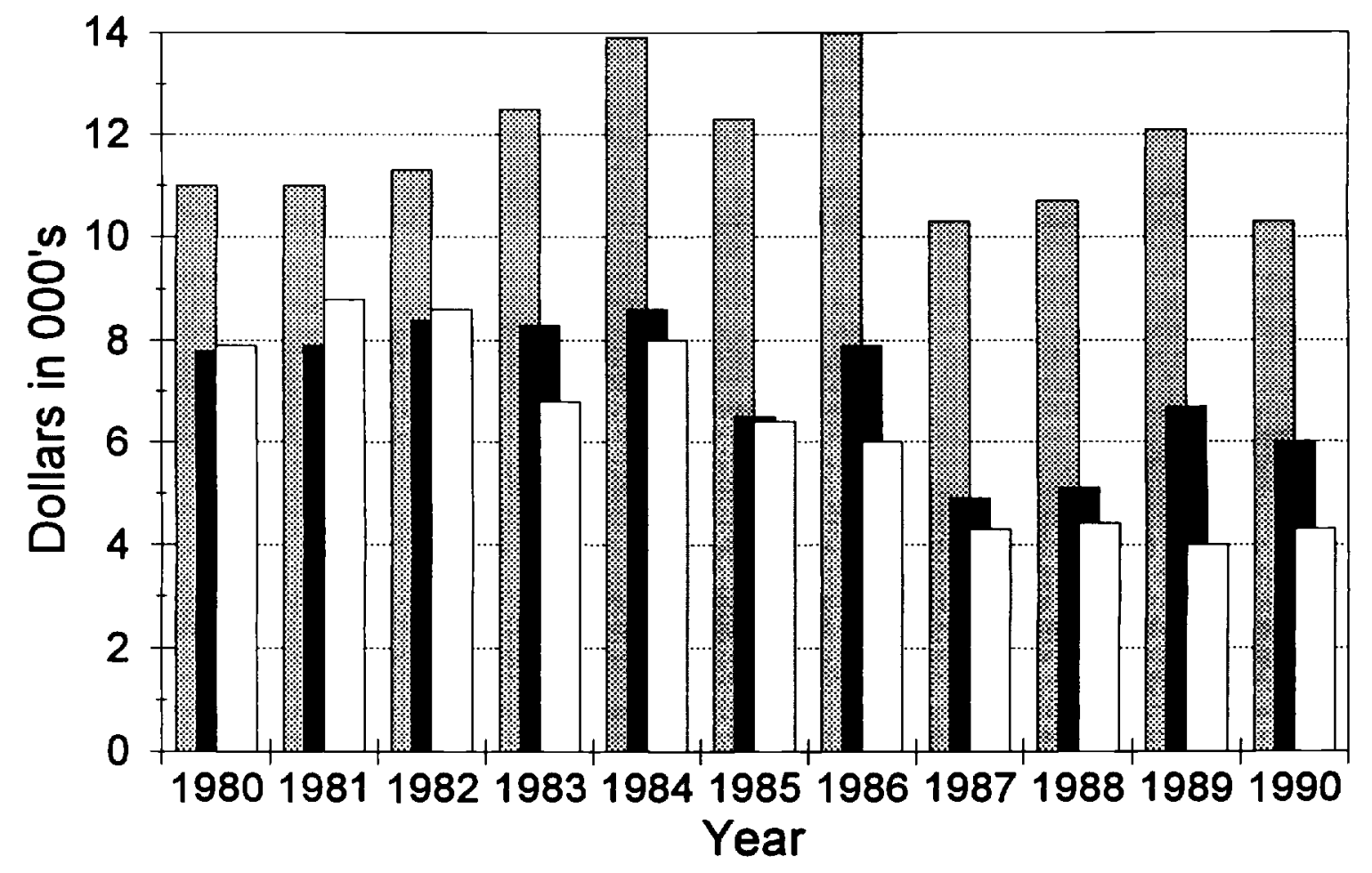

FOF Unadjusted $\square$ FOF NIPA Basis $\square$ NIPA 


\section{Fig 4.2. National Saving Levels And Total Retirement Contributions}

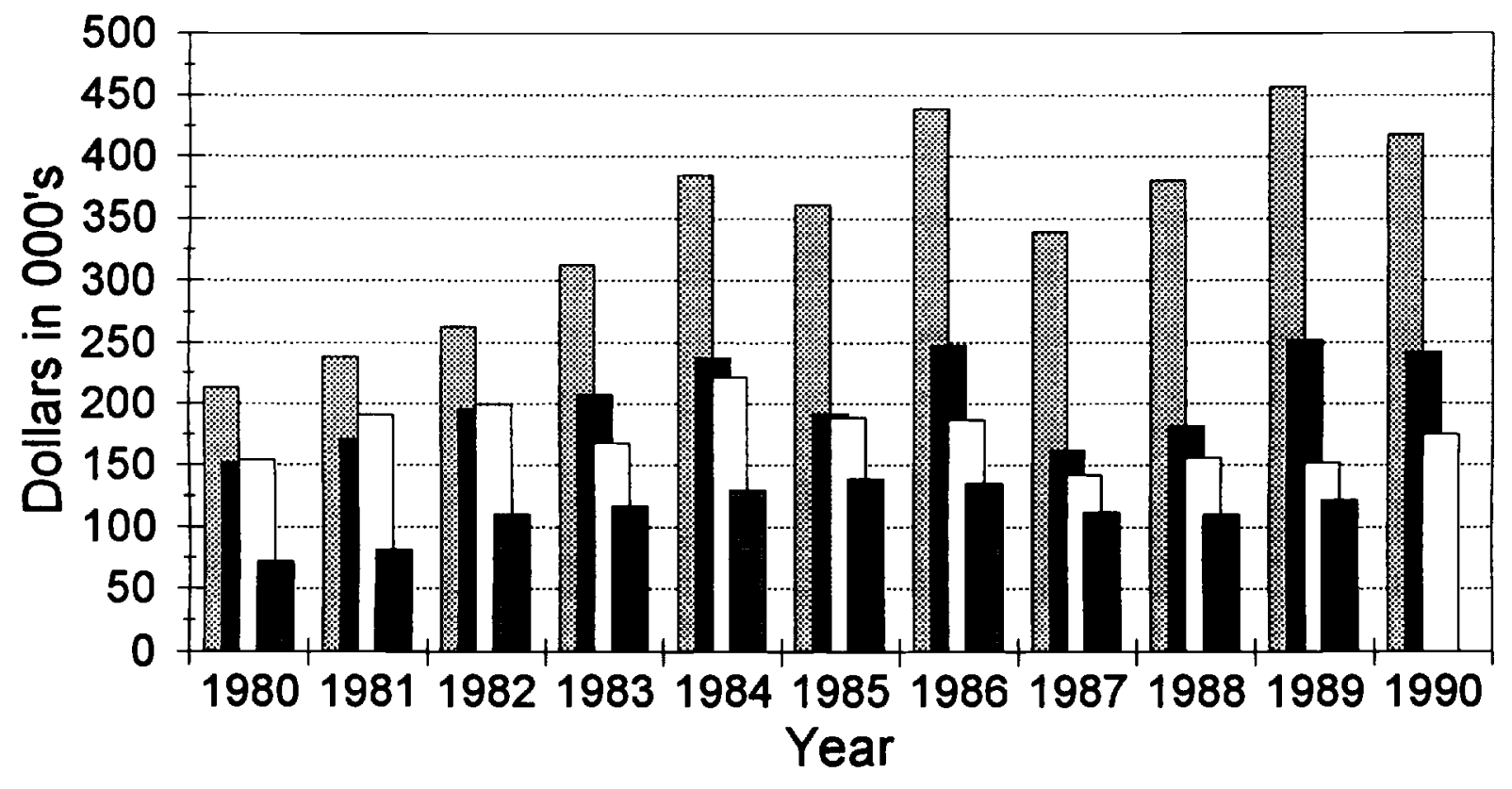

\begin{tabular}{|l|l|}
\hline FOF Unadjusted & FOF NIPA Basis \\
$\square$ NIPA & Ret Cont Total \\
\hline
\end{tabular}

